In marginal cases the presence of a thymoma, age over 50 years, bulbar involvement, and a thoracotomy or sternum-splitting incision are other factors favouring the need for tracheostomy and artificial ventilation. In this series patients who had artificial ventilation required it for more than 12 days (with the exception of one patient given tubocurarine), and we believe that if artificial ventilation is predicted as being necessary then tracheostomy, if not already done, should be performed at the time of thymectomy to spare the patient days of discomfort with an endotracheal tube.

We suggest that there are two safe policies for the management of the patient with myasthenia gravis subjected to thymectomy. The first is routine tracheostomy and artificial ventilation, which allows withdrawal of anticholinesterases in safety and avoids the problem of manipulation of drugs in the immediate postoperative period. In our opinion, however, this policy entails needless tracheostomy and ventilation in many patients. The second safe policy described here is to continue the preoperative drug regimen in the postoperative period and select patients preoperatively for tracheostomy and artificial ventilation principally on the preoperative vital capacity. Compromise within these two policies is likely to lead to emergency intubation and tracheostomy in unfavourable circumstances.

We wish to acknowledge the skill and attention of our surgical colleagues the late Mr. L. Pile, Mr. A. J. Gunning, and especially Mr. C. Grimshaw, who performed most of the thymectomies and introduced the new surgical approach mentioned in the text. We also thank the staff of the respiration unit at Churchill Hospital who helped with the care of these patients.

Requests for reprints should be addressed to: Dr. A. C. Young, Department of Neurology, Churchill Hospital, Headington, Oxford.

\section{References}

Crawford, J. (1971). Anaesthesia, 26, 513.

Havard, C. W. H. (1973). British Medical Fournal, 3, 437.

Kirschner, P. A., et al. (1969). Fournal of the American Medical Association, $209,906$.

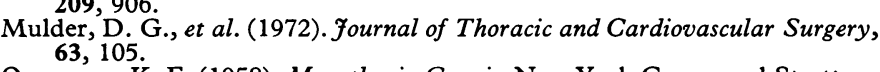

Osserman, K. E. (1958). Myasthenia Gravis. New York, Grune and Stratton. Osserman, K. E., and Genkins, G. (1971). Mount Sinai fournal of Medicine, 38, 497.

Schwab, R. S., et al. (1964). Fournal of the American Medical Association, 187,850 .

\title{
Acute Lymphoblastic Leukaemia: A Heterogenous Disease
}

\author{
D. G. HAEGERT, J. STUART, J. L. SMITH
}

British Medical fournal, 1975, 1, 312-315

\section{Summary}

By using several techniques to detect surface markers on $T$ and $B$ lymphocytes, 11 cases of acute lymphoblastic leukaemia (A.L.L.) were studied. In four cases an insignificant number of markers were detected on the lymphoblast populations. In one case a significant number of blasts formed both sheep red blood cell rosettes and Fc rosettes, suggesting a $\mathbf{T}$-cell origin for the neoplastic cells, and in another case the presence of Fc and C3 receptors on the lymphoblast population indicated a B-cell origin. In a further five cases $14-43 \%$ of the blasts had detectable surface immunoglobulin. It is concluded that A.L.L. is a heterogeneous disorder, some cases failing to express surface markers and others having either a T-or a B-lymphocyte origin or both.

\section{Introduction}

Lymphocytes derived from human bone marrow (B lymphocytes) express on their surface immunoglobulin (Ig) determinants (Pernis et al., 1971), receptors for fixed IgG (Hallberg et al., 1973), and receptors for activated C3 (Bianco et al., 1973). Thymus-derived lymphocytes ( $T$ lymphocytes), on the other hand, have an affinity for non-sensitized sheep red blood cells (R.B.C.) (Lay et al., 1971), with some T cells also expressing Fc

\footnotetext{
University Departments of Immunology and Haematological Medicine, Addenbrooke's Hospital, Cambridge CB2 2 QQ

D. G. HAEGERT, M.D., F.R.C.P., Research Fellow, Department of Im-

J. L. SMITH, PH.D., Research Fellow, (Present address: Immunology Unit, Tenovus Research Laboratory, General Hospital, Southampton SO9 4XY)

Department of Haematology, Children's Hospital, Birmingham B16 J. STUART, M.D., F.R.C.P., Consultant Haematologist
}

and C3 receptors (Dickler et al., 1974). These B- and Tlymphocyte markers have been used by many workers to investigate such neoplasms as chronic lymphatic leukaemia (C.L.L.) (Preud'homme and Seligmann, 1972; Dickler et al., 1973; Ross et al., 1973), acute lymphoblastic leukaemia (Seligmann et al., 1972; Berella and Sen, 1973; Kersey et al. 1973), prolymphocytic leukaemia (Catovsky et al., 1973), and leukaemic reticuloendotheliosis (Catovsky et al., 1974 a; Haak et al., 1974).

Previously we were unable to show T- and B-lymphocyte markers on A.L.L. lymphoblasts (Collins et al., 1974) though several recent reports suggest that some cases of A.L.L. are Tcell neoplasms (Borella and Sen, 1973; Seligmann et al., 1973; Belpomme et al., 1974; Catovsky et al., 1974 b). We described a single case of A.L.L. with two distinct neoplastic populations, one of T-cell and one of B-cell origin (Haegert et al., 1974 a), and report here our recent findings in 11 cases of A.L.L. using four rosetting reactions (Haegert et al., 1974 a), presenting evidence that in six cases the neoplastic cells expressed Blymphocyte surface markers.

\section{Methods}

Peripheral Blood Lymphocyte Preparations.-Peripheral blood from 11 patients, aged 5-62 years, with A.L.L. (see table) was collected into heparinized bottles and the erythrocytes were sedimented with $0.6 \%$ dextran. The leucocyte-rich supernatants were centrifuged on a mixture of Ficoll and sodium metrizoate ${ }^{19}$ (Thorsby and Bratlie, 1970), and the lymphocytes were collected as a band at the interface. The lymphocyte suspensions were washed three times with Hepes-Hanks's balanced salt solution supplemented with $0.2 \%$ bovine serum albumin then made up to a final suspension of $2.0 \times 10^{9}$ cells in Hepes-MEM (Eagle's medium) with $0.2 \%$ bovine serum albumine. The final suspensions contained less than $5 \%$ nonlymphoid cells.

Rosette Tests.-To detect lymphocytes with affinity for nonsensitized sheep R.B.C. a sheep R.B.C. rosetting technique was used. Fc receptors, C3 receptors, and Ig determinants were detected by rosetting reactions (Haegert et al., 1974 a). For scanning purposes 
cytocentrifuge preparations of the rosette tests were made then stained with Leishman's stain (Collins et al., 1974; Smith and Haegert, 1974).

Enzymatic Digestion.-Aliquots of the washed lymphocyte suspensions of a single patient (case 11) were treated with Vibrio cholerae neuraminidase (Mehrishi and Zeiller, 1974). The treated cells were then washed immediately and rosetted in all four rosetting experiments. In other experiments cells from this same patient were treated with trypsin $\left(2.5 \mathrm{~g} / 1\right.$ for $30 \mathrm{~min}$. at $37^{\circ} \mathrm{C}$ ) (Preud'homme and Seligmann, 1972) then washed and left overnight in bicarbonatebuffered M.E.M. with $10 \%$ heat-inactivated calf serum at $37^{\circ} \mathrm{C}$ before rosetting in all four test reactions.

Immunofluorescent Staining.-Polyvalent rabbit antihuman Ig antisera were raised in the laboratory. Fluorescein-labelled goat anti-rabbit Ig was obtained from Nordic Pharmaceuticals, Tilburg, Holland. Membrane fluorescence was performed using the indirect technique. Control preparations using normal rabbit serum were included in all experiments. All preparations were kept on ice then scored under a phase microscope fitted with an ultraviolet epiluminescent lamp.

\section{Results}

Peripheral blood lymphocyte preparations from 11 patients with A.L.L. contained variable percentages $(8-93 \%)$ of blasts. By using a cytocentrifuge technique (Collins et al., 1974; Smith and Haegert, 1974) blast populations could be clearly defined except in the mixed antiglobulin test for surface Ig (M.A.G. reaction) in which prior formaldehyde fixation of the lymphocytes interfered with Leishman staining. In control rosetting reactions with unsensitized ox cells and ox cells coated with IgM anti-ox R.B.C. antibody less than $4 \%$ of the blasts formed rosettes. Control preparations for the indirect immunofluorescence experiments gave essentially negative reactions, with less than $1 \%$ of the blasts staining.

In four cases significant numbers of surface markers could not be detected on the lymphoblast populations $(<5 \%$; see table). In one case (case 3) a significant number $(>10 \%)$ of lymphoblasts formed sheep R.B C rosettes and Fc rosettes, but in no other case did a significant number of blasts form sheep R.B.C. rosettes. In cases 8 and 9 a significant number of blasts had Fc receptors, while in case 9 a significant number of blasts also had $\mathrm{C} 3$ receptors. In five cases (cases 5, 6, 7, 8 and 11) the total number of cells with surface Ig determinants (detected either by the M.A.G. reaction or by immunofluorescence) significantly overlapped the number of blasts in the preparations examined, which suggested that $14-43 \%$ of the neoplastic cells had surface Ig determinants (see table).
In case 11 treatment of the A.L.L. cells with neuraminidase did not increase the number of cells reacting in the rosette tests. After treatment of an aliquot of lymphoid cells with trypsin followed by overnight incubation there was no change in any of the four surface markers evaluated.

\section{Discussion}

We examined 11 cases of A.L.L. for four surface markers using a previously developed cytocentrifuge technique (Collins et al., 1974; Smith and Haegert, 1974) which can yield important information from leukaemic populations containing few or many neoplastic cells, principally because we can characterize cytologically the lymphoid cells forming rosettes. In four cases less than $5 \%$ of the lymphoblasts formed sheep, Fc, or C3 rosettes, and there was no evidence of surface $\mathrm{Ig}$ on these cells. The meaning of a few blasts forming rosettes in the marker tests is obscure and probably was a result of our technique. Cytocentrifugation of control A.L.L. preparations in the Fc, C3, and M.A.G. rosette tests produced non-specific erythrocyte rosettes around less than $4 \%$ of the lymphoblasts.

In one case over $10 \%$ of the lymphoblasts formed sheep erythrocyte and Fc rosettes. Though surface Ig was not evaluated and experiments were not performed to see if these markers were present on the same cells the findings suggest a $\mathrm{T}$-cell origin for the blast population. This case seems analogous to those of T-cell lymphomas in mice which express Fc receptors (Grey et al., 1972; Harris et al., 1973). In another case the lymphoblasts formed significant numbers of Fc and C3 rosettes, while the M.A.G. test did not suggest that significant numbers of these cells had surface Ig. Since some normal B cells have readily detectable $\mathrm{C} 3$ receptors but not Ig determinants (Ross et al., 1973) these findings suggest a B-lymphocyte origin for the neoplastic cells.

In a further five cases of A.L.L. detection of surface Ig by either the fluorescent antibody or M.A.G. test did suggest that a significant number of the blast cells had surface Ig (the number of cells with surface Ig being too great to be accounted for by the normal population alone). In these cases a few lymphoblasts also rosetted in the $\mathrm{Fc}$ and $\mathrm{C} 3$ reactions. Since the controls in the M.A.G. test and controls stained with fluorescein-labelled antisera and normal sera in the indirect test gave essentially negative reactions $(<3 \%)$ the detected $\mathbf{~ I g}$ seemed not to be cytophilic antibody. Moreover, trypsin digestion (Preud'homme and Seligmann, 1972) of the lymphoblast population in one case followed by overnight incubation did not decrease the number of Ig-positive cells detected. All this evidence suggests that in this case at least the lymphoblasts expressed surface Ig and were of B-cell origin. Treatment of

B-and T-Lymphocyte Markers on Lymphocytes from Patients with Acute Lymphoblastic Leukaemia. Surface-marker Results expressed as Percentages of Cells Reacting with Specific Indicator System*

\begin{tabular}{|c|c|c|c|c|c|c|c|c|c|c|c|}
\hline \multirow{3}{*}{$\begin{array}{l}\text { Case } \\
\text { No. }\end{array}$} & \multirow{3}{*}{$\begin{array}{l}\text { Type of specimen } \\
\text { at Presentation } \\
\text { (P) or Relapse } \\
\text { (R) }\end{array}$} & & & & \multirow{3}{*}{$\begin{array}{l}\% \text { Blasts in } \\
\text { Lymphocyte } \\
\text { Preparation }\end{array}$} & \multirow{3}{*}{$\begin{array}{c}\text { T-cell } \\
\text { Marker } \\
\text { (Sheep R.B.C. } \\
\text { Rosettes) }\end{array}$} & \multicolumn{3}{|c|}{$\frac{\text { Surface Markers }}{\text { B-cell Markers }}$} & \multirow{3}{*}{$\underset{(B+T)^{ \pm}}{\text {Total }}$} & \multirow{3}{*}{$\begin{array}{c}\% \text { Blasts } \\
+(B+T) \S\end{array}$} \\
\hline & & \multicolumn{3}{|c|}{ Findings at Presentation } & & & & B-cell Markers & & & \\
\hline & & $\begin{array}{c}\text { Age } \\
\text { (Years) }\end{array}$ & $\begin{array}{l}\text { Peripheral Blood } \\
\text { W.B.C. }\left(\times 10^{\circ} / 1\right)\end{array}$ & $\begin{array}{c}\% \\
\text { Blasts }\end{array}$ & & & Fc Rosettes & C3 Rosettes & $\begin{array}{l}\text { M.A.G. } \\
\text { Rosettes }\end{array}$ & & \\
\hline $\begin{array}{r}1 \\
2 \\
3 \\
4 \\
5 \\
6 \\
7 \\
8 \\
9 \\
10 \\
11\end{array}$ & $\begin{array}{l}\text { P.B. (R.) } \\
\text { P.B. (R.) } \\
\text { B.M. } \\
\text { P.B. (R.) } \\
\text { P.B. (P.) } \\
\text { P.B. (P.) } \\
\text { P.B. (P.) } \\
\text { P.B. (P.) } \\
\text { P.B. (R.) } \\
\text { P.B. (P.) } \\
\text { P.B. (R.) }\end{array}$ & $\begin{array}{r}16 \\
15 \\
62 \\
3 \\
60 \\
52 \\
25 \\
8 \\
2 \\
6 \\
7\end{array}$ & $\begin{array}{l}6 \cdot 3 \\
35 \\
1 \cdot 3 \\
90 \\
7 \cdot 7 \\
6 \\
7 \cdot 1 \\
24 \cdot 4 \\
1 \\
17 \cdot 8 \\
43 \cdot 4\end{array}$ & $\begin{array}{l}50 \\
95 \\
2 \\
90 \\
52 \\
26 \\
64 \\
80 \\
18 \\
66 \\
50\end{array}$ & $\begin{array}{r}8 \\
71 \\
63 \\
66 \\
88 \\
90 \\
90 \\
89 \\
78 \\
89 \\
93\end{array}$ & $\begin{array}{l}3(40) \\
0(4) \\
12(12) \\
4(23) \\
5(4) \\
5(13) \\
0(3) \\
5(9) \\
1(2) \\
0(3) \\
0(0)\end{array}$ & $\begin{array}{l}2(33) \\
0(5) \\
10(10) \\
4(17) \\
9(14) \\
7(13) \\
\text { N.D. } \\
17(10) \\
30(24) \\
0(5) \\
3(4)\end{array}$ & $\begin{array}{l}0(1) \\
0(0) \\
0(0) \\
3(8) \\
\text { N.D. } \\
3(3) \\
\text { N.D. } \\
6(8) \\
16(24) \\
2(4) \\
4(10)\end{array}$ & $\begin{array}{l}(20) \\
(21) \\
\text { N.D. } \\
(11) \\
(40) \dagger \\
(26) \\
(50) \dagger \\
(33) \\
(8) \\
(9) \\
(20)\end{array}$ & $\begin{array}{l}73 \\
25 \\
40 \\
44 \\
39 \\
53 \\
42 \\
26 \\
12 \\
21\end{array}$ & $\begin{array}{r}81 \\
96 \\
\\
106 \\
132 \\
129 \\
143 \\
131 \\
104 \\
101 \\
114\end{array}$ \\
\hline
\end{tabular}

*Values in parentheses represent total percentage of cells, both neoplastic and non-neoplastic, reacting with given indicator system. Values not in parentheses represent percentage of neoplastic cells reacting with given indicator system.

†Surface Ig determinants were recognized by indirect immunofluorescence.

Sum of percentage of total cells, neoplastic and non-neoplastic, with T-lymphocyte marker and highest percentage of cells with any B-cell marker.

S Sum of percentage of blasts in preparation and total percentage of cells recognized by both $T$ and $B$ markers.

N.D. = Not done.

Conversion: SI to Traditional Units-W.B.C. $1 \times 10^{\circ} / 1=1000 / \mathrm{mm}^{3}$ 
these lymphoblasts with neuraminidase (Chapel, 1973; Mehrishi and Zeiller, 1974) did not increase the number of cells with markers and failed to show masked determinants.

It is noteworthy that four out of the five patients with detectable $\mathrm{Ig}$ on the surface of their lymphoblasts were investigated at presentation before treatment. Further studies are planned to investigate if these lymphoblasts with surface Ig persist during the course of the disease. The findings in one patient (case 11) suggest that they do. Apart from this observation there was no correlation between the presence or absence of markers with the prognostic assessment at diagnosis, based on leucocyte count, percentage blasts, and presence or absence of mediastinal enlargement on chest $x$-ray picture.

Nevertheless, important information can be obtained by characterizing surface markers on A.L.L. lymphoblasts. Such an approach may be clinically important in the early classification of cases of A.L.L. since there is some evidence that cases of Tcell origin have an exceptionally poor prognosis (Borella and Sen, 1973; Catovsky et al., 1974 b). The important observation that some A.L.L. lymphoblasts express B-cell markers, together with other recent findings (Haegert et al., $1974 \mathrm{~b}$ ), suggest that A.L.L. is a disease of heterogeneous origin divisible into at least four groups-those without surface markers, those with $\mathrm{T}$ - or B-cell markers, and those cases expressing combined T- and Bcell determinants (Haegert et al., $1974 \mathrm{~b}$ ).

J. L. Smith was supported by the Leukaemia Research Fund, D. G. Haegert by a fellowship from the Medical Research Council of Canada.

Requests for reprints should be addressed to J. L. Smith,
Immunology Unit, Tenovus Research Laboratory, General Hospital, Southampton S09 4XY.

\section{References}

Belpomme, D., et al. (1974). Biomedicine, 20, 109.

Bianco, C., Patrick, R., and Nussenzweig, B. (1970). Fournal of Experimental Medicine, 132, 702 .

Borella, L., and Sen, L. (1973). Fournal of Immunology, 3, 1257.

Catovsky, D., et al. (1973). Lancet, 2, 232 .

Catovsky, D., et al. (1974 a). British fournal of Haematology, 26, 29.

Catovsky, D., et al. (1974 b). British Medical fournal, 2, 643.

Chapel, H. M. (1973). Transplantation, 15, 320.

Collins, R. D., et al. (1974). British fournal of Haematology, 26, 615

Dickler, H. B., et al. (1973). Clinical and Experimental Immunology, 14, 97.

Dickler, H. B., Adkinson, N. F., jun., and Terry, W. D. (1974). Nature, 247,213

Grey, H. M., Kubo, R. T., and Cerottini, J. C. (1972). Fournal of Experimental Medicine, 136, 1323.

Haak, H. L., et al. (1974). British fournal of Haematology, 27, 31.

Haegert, D. G., Hallberg, T., and Coombs, R. R. A. (1974 a). International Archives of Allergy, 46, 525.

Haegert, D. G., et al. (1974 b). British Medical fournal, 4, 79.

Hallberg, T., Gurner, B. W., and Coombs, R. R. A. (1973). International Archives of Allergy, 44, 500 .

Archives of Allergy, 44, Fournal of Immunology, 110, 431.
Harris, A. W., et al. (1973). Fournal

Harris, A. W., et al. (1973). Fournal of Immunolog

Kersey, J. H., et al. (1973). Science, 182, 13

Lay, W. H., et al. (1971). Nature, 230, 531.

Pernis, B., et al. (1971). In Progress in Immunology, ed. B. Amos, p. 96. New York, Academic Press.

Preud'homme, J. L., and Seligmann, M. (1972). Blood, 40, 777

Ross, G. D., et al. (1973). Fournal of Clinical Investigations, 52, 377.

Seligmann, M., Preud'homme, J. L., and Brouet, J. C. (1973). Transplantation Reviews, 16, 85.

Smith, J. L., and Haegert, D. (1974). Clinical and Experimental Immunology, 17,547 .

Thorsby, E., and Bratlie, A. (1970). In Histocompatibility Testing 1970, P. I. Terasaki, p. 655. Copenhagen, Munksgaard.

\section{MEDICAL MEMORANDA}

\section{Successful Thymus Graft for T-cell Deficiency in a 6-year-old Boy}

\author{
N. FOROOZANFAR, M. YAMAMURA, \\ G. WATSON, P. WEAVER, E. M. BELTON, \\ S. LAWLER, J. R. HOBBS
}

British Medical fournal, 1975, 1, 314-315

Thymus transplantation in patients with DiGeorge's syndrome (August et al., 1968; Cleveland et al., 1968) has been shown to produce rapid and dramatic reconstitution of cellmediated immunity. Temporary reconstitution of cellmediated immunity (Levy et al., 1971) but not of humoral immunity (Amman et al., 1973) has been achieved in vari-

\footnotetext{
Department of Chemical Pathology, Westminster Hospital Medical School, London SW1P 2AR

N. FOROOZANFAR, M.D., British Council Fellow

M. YAMAMURA, M.SC., Research Fellow

J. R. HOBBS, M.D., F.R.C.P., Professor of Chemical Pathology

Westminster Hospital, London SW1P 2AR

P. WEAVER, F.R.c.s., Senior Registrar in Surgery

Westminster Children's Hospital, London S.W.1

G. WATSON, M.R.C.P., D.C.H., Lecturer in Child Health

St. Peter's Hospital, Chertsey, Surrey

E. M. BELTON, M.B., M.R.C.P., Consultant Paediatrician

Royal Marsden Hospital, London S.W.3 S. LAWLER, M.D., M.R.C.P., Head of Department of Cytogenics and
}

ous immunodeficiency diseases. We report the successful grafting of a fetal thymus into a 6-year-old boy with $T$ lymphocyte deficiency proved on three occasions before the operation.

\section{Case Report}

A 6-year-old Caucasian boy was admitted to hospital with a history of repeated respiratory infections. $\mathrm{He}$ was regularly off school three days out of four and was almost continuously on antibiotics. $\mathrm{He}$ was an adopted child and had a half-brother aged 7 years, also adopted by the same family. They had the same mother but different fathers.

The patient had normal facies and none of the features of DiGeorge's syndrome. He was apparently well until the age of 1 year, when he began to have feverish illnesses with coughs, diagnosed as bronchitis, which responded to antibiotics. Various antibiotics had been prescribed over a relatively short period. His doctor had tried on one or two occasions to leave him without antibiotics but he became rapidly worse and eventually had to be given antibiotics. He showed no eczema and sneezing was not a feature though wheezing was common. At one stage he developed severe allergy to streptomycin. He received quadruple immunization, oral polio vaccine, and, later, measles vaccination. His mumps and chickenpox were no worse illnesses than those of his brother and he had not had measles. He had frequent attacks of pneumonia and clearly had a much higher tendency to infections than did his brother.

\section{INVESTIGATIONS}

\section{Methods and Materials}

Lymphocyte transformation to phytohaemagglutinin (PHA) was done according to the standardized method of Yamamura (1973) and to candida immunogen by the standardized method of 